Ann-Kristin Helland Gujord

Institutt for lingvistiske, littercere og estetiske studium

Universitetet i Bergen

E-post: Ann-Kristin.Gujord@uib.no

\title{
"Hos en voksen er tanken helt full av masse ting." Personlege narrativar i Norsk andrespråkskorpus (ASK) - ei kjelde til innsikt i læringsprosessen?
}

\section{Samandrag}

I denne artikkelen utforskar eg utvalde tekstar frå Norsk andrespråkskorpus (ASK) som personlege narrativar. I norsk andrespråksforsking finst det knappast forsking på innlceraranes beskrivingar av sjølvopplevd språklcering, og ASK har så langt i all hovudsak vore nytta til å granska grammatiske og leksikalske trekk ved andrespråkstileigning. Analysen av 38 tekstar frå ASK viser at korpuset også kan nyttast til å granska sjølve innhaldet i tekstar der innlcerarane skriv om språklæring basert på erfaring.

Nøkkelord: andrespråkstileigning, vaksne innvandrarar, Norsk andrespråkskorpus (ASK), personlege narrativar

\begin{abstract}
This article explores a sample of texts from the Norwegian learner corpus (ASK) as personal narratives. In Norwegian second language acquisition, research on learners' language learning experience has been scarce, and ASK has so far mainly been exploited as a source of insight into L2 learners' grammatical and lexical development. The present analysis of 38 texts from ASK demonstrates, however, that the corpus may also be useful to content analyses of texts in which learners write about their own experiences.
\end{abstract}

Keywords: L2 learning, adult immigrants, Norwegian learner corpus (ASK), personal narratives

Narrativar i andrespråksforskinga

Dei siste tiåra har ei særskilt form for forteljande tekst, personlege narrativar, vorte ei mykje brukt form for data innan forskinga på fleirspråklegheit og språklæring (Pavlenko, 2007; Barkhuizen, Benson \& Chik, 2014). Personlege narrativar er forteljingar "based on speakers' personal knowledge and experience" 
(Pavlenko, 2008, s. 317), og i denne artikkelen diskuterer eg om Norsk andrespråkskorpus (ASK) kan nyttast som datagrunnlag for utforskinga av vaksne innlærarars sjølvopplevde erfaringar med språklæring. Eg ønskjer å finna ut kva ein kan få ut av ASK-korpuset om språklæring ved å granska synspunkta og beskrivingane sette fram av dei vaksne innlærarane sjølve i eit utval av tekstar.

Mange studiar av innlærarspråk har nytta narrativar som empiri, men hovudvekta av forskinga skil seg frå den fagtradisjonen denne undersøkinga kviler seg på, både når det gjeld forskingsføremål og måten narrativen vert definert og analysert på. Føremålet i dei fleste narrative studiane har tradisjonelt vore å granska utviklinga av grammatisk og leksikalsk kompetanse, eller narrativ kompetanse. Studiane som granskar personlege narrativar er derimot lite opptekne av form, men analyserer innhaldet i tekstane for å få innsikt i innlærarane sine eigne erfaringar, til dømes med det å læra eit nytt språk i vaksen alder. Det viktigaste kjenneteiknet ved den narrative teksten i denne tilnærminga er at den rommar forteljarens fortolking og framstelling av ei eller fleire livserfaringar, som er kommunisert fram i ein gitt kontekst. Ein stiller ikkje formelle krav til teksten, slik ein gjer innanfor andre fagtradisjonar, særleg tekstvitskapen, der narrativen vert rekna som ei tekstleg grunnform (Breivega \& Johansen, 2016, s. 54). For at ein tekst skal kunne klassifiserast som narrativ, og ikkje berre beskrivande, må den innehalda bestemte komponentar og språklege trekk. Denne tekstteoretiske tradisjonen har vore betydingsfull i andrespråksforskinga, særskilt innanfor studiet av utvikling av narrativ kompetanse på andrespråket (t.d. Berman, 2001; Berman \& Slobin, 1994). I denne retninga har ein også av metodiske omsyn helst nytta fiksjonsnarrativar, det vil seia forteljingar om hendingar som ikkje har skjedd, i staden for narrativar som byggjer på forteljaren si eiga erfaring og kunnskap (Pavlenko, 2008, s. 311-312 og 317). Forskinga på fiksjonsnarrativar er også ein godt etablert tradisjon i motsetnad til forskinga på personlege narrativar som er "just beginning to gain recognition" (Pavlenko, 2008, s. 317). Dei fleste norske andrespråksstudiane som baserer seg på narrativar, undersøkjer grammatisk utvikling, leksikalsk utvikling eller utvikling av narrativ kompetanse, og nyttar hovudsakleg fiksjonsnarrativar. Eit døme er Nistov (2001) sin studie av referentkopling hos tre tyrkiske norskinnlærarar basert på deira attforteljingar av Pærehistoria (The Pear Story). Fiksjonsnarrativar er også datagrunnlaget i Berggreen, Sørland og Alver (2012) der gangen i utviklinga av narrative tekstar er granska hos minoritetsspråklege elevar på mellomtrinnet over tid, og Selj (2010) granskar narrative tekstar skrivne på skulen av minoritetsspråklege ungdomsskuleelevar. Sjølv om ikkje studiet av personlege narrativar er utbreidd i norsk andrespråksforsking, har ein av metodane for å samla denne typen tekstar, intervju, vore ein hyppig brukt metode; til dømes intervjuar Svendsen (2004) norsk-filippinske barn og deira foreldre om språkval. 


\section{Personlege narrativar}

Ei felles grunnleggjande antaking i litteraturen om personlege narrativar er at menneske er forteljande vesen som skapar meining og forståing av sine livserfaringar gjennom å fortelja om dei. Denne tenkemåten er tett knytt til psykologen Jerome Bruner (1990, 1987), men tankar om forteljinga som ei fundamental fortolkingsform for mennesket har ei lang historie (sjå f.eks. Atkinson, 1998; Connelly \& Clandinin, 1990; Murray, 2009), og fleire ved sida av Bruner er viktige premissleverandørar for teoriutviklinga i dette feltet. I denne fagoverskridande forskingstradisjonen er livserfaringa og fortolkinga av den kjerna, men erfaringane vert først narrativar når dei vert underlagde ein narrativ analyse (Barkhuizen, 2015, s. 169). Omgrepet 'narrativ' er altså eit fagomgrep, og ein må skilja mellom fenomenet forteljingar ('story'), det at folk gjennom alle tider har fortalt forteljingar, og forskinga på slike tekstar ('narrative') (Connelly \& Clandinin, 1990, s. 2). Framveksten av denne tilnærminga til narrativen innanfor samfunnsvitskaplege og humanistiske disiplinar på 1990-talet vert gjerne kalla den narrative vendinga ("the narrative turn") (f.eks. Barkhuizen, 2015, s. 170; Barkhuizen, Benson \& Chik, 2014, s. 1; Palvlenko, 2007, s. 164; Riessman, 2001, s. 169; Selj, 2010, s. 36). I andrespråksforskinga heng denne utviklinga saman med inntoget av meir sosialt-orienterte tilnærmingar, ei utvikling som vert omtala som den sosiale vendinga ("the social turn") (Block, 2003), og som viser til teoriutviklinga innan feltet på 1990-talet. Den narrative vendinga var med andre ord ein del av ein større trend mot meir kvalitativt orientert forsking innanfor den anvendte språkvitskapen, inkludert andrespråksforskinga (Block, 2003; Norton \& McKinney, 2011, s. 82). Studiet av personlege narrativar er situert og kontekstualisert forsking (Barkhuizen, 2015, s. 171), og har ikkje som mål å generalisera, jamfør følgjande sitat frå Murray (2009): "If researchers are looking for results which can be generalized, this [narrative inquiry] is not the form of research they should be pursuing” (s. 58). Ifølgje Barkhuizen (2015) var den narrative vendinga eit uttrykk for at forskarane byrja å forstå "the importance of paying attention to how language teachers and learners use stories to make sense of their experience” (s. 170). Det er altså ikkje berre andrespråksinnlærarane sine forteljingar som er forskingsobjektet (som f.eks. i Burck, 2005; Pavlenko, 2004; Schumann, 1980), men også forteljingane til andrespråkslærarar (f.eks. Barkhuizen, 2008; Vasquez, 2007). Innanfor andrespråksforskinga er det særleg i utforskinga av identitet at personlege narrativar har vore nytta som datagrunnlag (Taniguchi, 2010, s. 212; Vasquez, 2011, s. 535; Norton \& McKinney, 2011, s. 82), men også i utforskinga av motivasjon (Murray, 2009, s. 47).

Personlege narrativar kan vera av ulike slag (Murray, 2009; Barkhuizen, Benson \& Chik, 2014; Young, 2013; Barkhuizen, 2015), men eg vil vidare i framstellinga basera meg på Pavlenko $(2007,2008)$ si inndeling. Pavlenko (2008, s. 318) deler personlege narrativar i tekstar om personlege erfaringar 
("personal experience narratives") og språkbiografiar ("linguistic autobiographies” eller "autobiographic narratives”). Språkbiografiane kan vidare vera av ulike typar, mellom anna dagbøker og notatar produserte spontant eller som respons på ei oppgåve, språkbiografiar eller livshistoriar som inkluderer beskriving av erfaringar med språklæring, eller memoarar (Pavlenko, 2007, s. 165). Vidare kan ein skilja mellom narrative studiar etter kva forskaren vil samla informasjon om. Studiar som vil utforska korleis innlærarane sjølve tenkjer rundt eigen læringsprosess, granskar "subject reality”. Studiar som også er interessert i korleis noko er eller var i omgjevnaden rundt innlæringa, granskar i tillegg "life reality" (Pavlenko 2007, s. 168). I nyare tid er det fleire studiar som granskar "text reality", det vil seia "how bilinguals construct selves in their respective languages [...] or in a second language [...], how L2 writers create textual homes in a second language [...], and how language learning experiences are reflected in L2 users' positioning and narrative plots” (Pavlenko, 2007, s. 170). Det er også fleire innan feltet som argumenterer for å inkludera fleire typar tekstar innanfor narrativsjangeren. Ei av dei er De Fina (2009) som hevdar at studiar av meir utypiske narrative tekstar kan tilføra feltet ny innsikt i samspelet mellom narrativen og dei diskursive rammene rundt den. De Fina (2009) granskar posisjonering og identitetsforhandlingar i munnlege utgreiingar, og utforskar med andre ord "text reality".

Pavlenko (2007, s. 164-165) reknar opp fleire område der studiet av innlæraranes beskrivingar av eiga erfaring er nyttige, og i denne samanhengen er det særleg to punkt som er sentrale: 1) Gjennom å få tilgang til språkinnlæraranes eigne refleksjonar og erfaringar med språklæring får forskaren eit unikt innanfrå-perspektiv på læringsprosessen, og på det å vera språkinnlærar og andrespråksbrukar, og 2) nye samanhengar som er viktige i læringsprosessen, kan dukka opp i denne typen tekstmateriale. Murray (2009, s. 58) peikar også på at sjølv om forskarar innanfor denne tilnærminga ikkje "engage in the quest for universals”, vil desse meir kvalitativt orienterte studiane kunna skaffa fram kunnskap som kan vera relevant for innlærarar i andre kontekstar. Det er også fleire (t. d. Norton \& Early, 2011; Nunan \& Choi, 2010; Murray, 2009) som peikar på eit anna viktig bidrag: I mange tilfelle vert marginaliserte grupper gitte ei stemme gjennom denne typen datamateriale. Chik (2008) hevdar til dømes at ein av føremonnane ved denne tilnærminga er at den "[...] advocates putting people at the centre of the research" (s. 27). Murray (2009, s. 47) understrekar også at denne typen forsking er viktig for "educators" og for "policy-making”.

Studiet av personlege narrativar kan altså tilføra feltet verdifull og nyttig kunnskap om ulike aspekt ved andrespråkslæring. Men Pavlenko (2007, 2008) peikar på ei grunnleggjande utfordring for forskinga, nemleg mangelen på metodemedvit og teorigrunnlag. Det er bakgrunnen for at ho stiller denne diagnosen: 
[...] narratives are among the most popular means of data collection in the study of bilingualism. Narrative analysis, however, is among the least understood and theorized means of data in the field [study of bilingualism]. (Pavlenko, 2008, s. 311)

Den mest utbreidde metodiske tilnærminga til eit slik materiale er ein analyse av temaa som går att i tekstane ("content and thematic analysis" hos Pavlenko, 2007; Barkhuizen, Benson \& Chik, 2014). Det gjeld særleg studiar som granskar "subject reality" (Pavlenko, 2007, s. 166). I mange av desse studiane manglar forskaren eit overordna analytisk blikk på systematiseringa av data. Det gjer ifølgje Pavlenko at for mange studiar av personlege narrativar endar opp med "a laundry list of observations, factors, or categories, illustrated by quotes from participants” (2007, s. 167) utan å analysera samanhengen desse inngår i. Samstundes peikar fleire forskarar på "grounded theory" og ei induktiv "bottom up" tilnærming til dataa, som eit nyttig teoretisk-metodisk utgangspunkt for denne typen narrativ analyse (Canagarajah, 1996; Young, 2013; Burck, 2005). Eit trekk ved ei slik tilnærming er at datainnsamling og analyse skjer parallelt. Pavlenko løftar fram eit anna problem med forskinga på personlege narrativar, og som særskilt gjeld studiane av "life reality" (2007, s. 168). Forskarane er ofte ikkje medvitne om konteksten eller diskursen narrativen har oppstått i, og kan ha ei manglande forståing av at det å fortelja inneber innslag av sjølvframstelling, selektering av informasjon og fortolking av erfaring frå den som fortel si side (Pavlenko, 2007, s. 168). Studiar som handsamar narrativane som «fakta” og ikkje konstruksjonar, har ikkje teke innover seg "the interpretive nature of narration” (Pavlenko, 2007, s. 169). Denne kritikken heng saman med ein annan type kritikk som også har vorte sett fram mot studiar av innlærarars eigne erfaringar, og som gjeld truverd i tekstane ("trustworthiness" hos Murray, 2009, s. 58; Barkhuizen, 2015, s. 176). Barkhuizen (2015, s. 176) kommenterer denne kritikken slik: "Narrative researchers do not aim to discover whether participants' stories are accurate reflections of their actual experience (as I have just said, they cannot anyway) but to understand the meaning people attach to those experiences”.

\section{Personlege narrativar i ASK?}

Innlærarane som skriv om erfaringane sine i denne undersøkinga er vaksne innvandrarar i aldersspennet 23 til 51 år som har bestått ein offisiell test i norsk. (Eksakt alder til alle dei 38 innlærarane er å finna i tabellen i vedlegg 1.) Tekstane deira er henta frå ASK, eit elektronisk innlærarkorpus som består av tekstar frå to ulike prøvar: Språkprøven i norsk for vaksne innvandrarar ${ }^{1}$ (Språkprøven), som målte på eit mellomnivå i norsk tilsvarande B1 i Det felles europeiske rammeverket for språk, og Test i norsk - høgare nivå som måler på B2/C1-nivå. Kandidatane har også fylt ut eit spørjeskjema som samlar personinformasjon som kjønn, alder, utdanning frå heimlandet, talet på timar 
med norskundervisning osv. (Tenfjord, Hagen \& Johansen, 2009). Eit viktig føremål med utviklinga av korpuset var å styrkja den kvantitative andrespråksforskinga i Noreg (Tenfjord, Hagen \& Johansen, 2009, s. 53-54). Eit fellestrekk ved ASK-studiane er at også dei byggjer på eit stort tal på tekstar, nyttar statistiske analysar og har som føremål å generalisera omkring grammatiske eller leksikalske aspekt ved innlæringa. I denne undersøkinga er det ikkje det grammatiske som er i fokus, men innhaldet i tekstane. ASK-tekstane spenner over fleire ulike typar tekstar og tema, og tekstane eg er interessert i, er dei som inneheld refleksjonar om språk og språklæring basert på erfaring og innsikt.

Tekstane i undersøkinga er ikkje alle skrivne til den same oppgåva, og tabell 1 gir eit oversyn over kva for oppgåver tekstane er responsar på, og kva test dei er teken som ein del av:

Tabell 1 Oversyn over oppgåvetypar inkluderte i undersøkinga

\begin{tabular}{|l|l|c|}
\hline Oppgåveformulering & Test & Tal på tekstar \\
\hline $\begin{array}{l}\text { Skriv en tekst om hvordan det er å lære et fremmed språk i } \\
\text { voksen alder }\end{array}$ & Språkprøven & 31 \\
\hline $\begin{array}{l}\text { Ta stilling til budskapet i “Ingen ting”, slik du oppfatter det. } \\
\text { Forklar hvordan du opplever det når du skal uttrykke tanker og } \\
\text { følelser på et annet språk enn ditt eget, for eksempel på norsk. }\end{array}$ & $\begin{array}{l}\text { Test i norsk - } \\
\text { høgare nivå }\end{array}$ & 3 \\
\hline Skriv en tekst om å flytte & Språkprøven & 1 \\
\hline Skriv en tekst om hva som gjør et sted trivelig å bo på & Språkprøven & 1 \\
\hline Skriv en tekst om et yrke & Språkprøven & 1 \\
\hline Fortell hvordan du liker å treffe andre mennesker & Språkprøven & 1 \\
\hline
\end{tabular}

Heile 31 av 38 tekstar kjem frå same oppgåve som handlar om språklæring i vaksen alder. Oppgåva gitt til testen på høgare nivå, er teken med fordi kandidatane vert eksplisitt bedne om å basera seg på eiga erfaring. Dei siste fire tekstane har ikkje svara på oppgåver der dei er bedne om å skriva om språk eller språklæring. Desse er likevel tekne med fordi kandidatane løyser oppgåva basert på sjølvopplevd erfaring med språk og språklæring.

Tekstane er også ulike i måten dei er utforma på. I oppgåva om framandspråkslæring er kandidatane inviterte, men ikkje direkte bedne om å trekkja på eigne erfaringar som vaksne språkinnlærarar. Kandidatane som har svara på denne oppgåva, har løyst den på hovudsakleg to måtar. Halvparten (15) skriv om si eiga tidlegare og/eller pågåande språklæring. Desse tekstane svarar til tekstar Pavlenko (2008) definerer som språkbiografiar, det vil seia tekstar som "focus on the languages of the speaker and discuss how and why these languages were acquired, used, or abandoned" (s. 319) ${ }^{2}$. Den andre halvparten (16) skriv meir generelt om det å læra eit nytt språk som vaksen, dels ut frå innsikt med referanse direkte eller indirekte til eiga eller andre si språklæringserfaring. I fleire av desse tekstane fungerer delar av teksten som språkbiografiar, men det er ikkje eit gjennomført grep slik me finn det i dei 15 tekstane eg reknar som språkbiografiar. I motsetnad til dei språkbiografiske tekstane er desse tekstane somme tider skrivne i første person, og somme tider skrivne med upersonleg pro- 
nomen $^{3}$. Desse 16 tekstane som ikkje er klart språkbiografiske, kan moglegvis klassifiserast som personlege erfaringsnarrativar ("personal experience narratives" hos Pavlenko, 2008) fordi synspunkta som vert sette fram hovudsakleg ser ut til å byggja på kunnskapar om eigne og andre sine erfaringar. Men dette er ikkje heilt uproblematisk, særleg fordi det også blant desse 16 tekstane finst tekstar der det er mindre klart om kandidaten baserer seg på erfaring, og der kandidaten ikkje nyttar førstepersonpronomen i det heile teke ${ }^{4}$. Desse tekstane kan beskrivast som refleksjonstekstar. Dei er utgreiingar som har oppstått som eit svar på eit spørsmål eller ei problemstilling som kandidaten reflekterer rundt. Ifølgje De Fina (2009) bør slike reflekterande utgreiingar likevel, og i aller høgste grad, reknast med innanfor den narrative sjangeren. Utgreiingar ("accounts" hos De Fina, 2009) er narrativar som oppstår som ein respons eller eit tilsvar på eit evaluerande spørsmål (s. 240) i motsetnad til personlege narrativar, som i si tradisjonelle form er responsar på opne spørsmål (s. 240). Sjølv om De Fina (2009) primært diskuterer munnlege utgreiingar, understrekar ho at "accounts are a very large class of narratives that do not only emerge in interviews, but can be produced in all kinds of situation" (s. 240). Det betyr at også utgreiingar som oppstår i ein testsituasjon, kan reknast som narrativar; det avgjerande er at diskursen rundt vert teken med når teksten vert analysert. Slik eg ser det, legg De Fina eit ytterlegare teoretisk grunnlag for å rekna desse 16 tekstane som narrativar. Dei fire tekstane om flytting, bumiljø, yrkeserfaring og om å treffe folk er hovudsakleg refleksjonstekstar, men der refleksjonane i enkelte parti eksplisitt byggjer på eiga erfaring. Desse fire tekstane plasserer seg altså også i grenseland mellom kategorien Pavlenko (2008) kallar erfaringsnarrativar og kategorien De Fina (2009) omtalar som "accounts". Når det gjeld dei tre tekstane skrivne til testen på høgare nivå, står desse først og fremst fram som personlege narrativar, sjølv om dei også har innslag av meir generelle refleksjonar.

Oppsummert er det altså slik at dei 38 tekstane alle kan reknast som narrativar, og dei har til felles at dei gir uttrykk for å vera kandidatens personlege synspunkt om språk og språklæring. Men tekstane er responsar på ulike oppgåveformuleringar, og det varierer i kva grad, og om, dei fortel direkte om eiga erfaring med språklæring eller reflekterer meir generelt om språk og språklæring. Alle tekstane er produserte i ein testsituasjon, der kandidatane er vel vitande om at både form og innhald skal vurderast av ein sensor, og der utfallet av testen kan ha viktige følgjer for kandidaten. Eg har så langt i faglitteraturen ikkje kome over tekstar produserte i ein testsituasjon som har vore nytta eller rekna som tekstar som formidlar personlege erfaringar, og det kan tenkjast at nokon vil stilla spørsmål ved validiteten til undersøkinga. Ifølgje De Fina (2009) si forståing av utgreiingar ("accounts”) kan og bør denne typen tekstar reknast blant narrativane, og er valide kjelder til innsikt i innlærarane sine eigne refleksjonar. Pavlenko (2008) nemner dessutan tekstar produserte som respons på ein stimulus, altså på “oppdrag” frå anten læraren eller forskaren, som ein måte å 
samla personlege narrativar på. Det avgjerande er at narrativane ikkje vert oppfatta å spegla faktiske realitetar, men at ein i analysen er medviten om den interaksjonelle konteksten for narrativane. Ei metodisk utfordring eg ser ved å bruka tekstar frå ASK som grunnlag for ein analyse av eit meiningsinnhald, er at innlærarane må uttrykkja synspunkta sine gjennom eit språk dei ikkje meistrar fullt ut, eit faktum som vil kunna leggja avgrensingar på kva dei får kommunisert.

\section{Analyse og funn}

Tilnærminga til dataa kan karakteriserast som innhaldsanalyse ("content analysis”). Eg forstår analyseeininga i tråd med Burck (2005) sin definisjon av "meaning-units", det vil seia "sentences or several sentences which referred to a particular meaning - rather than every single line" (s. 42). Denne typen innhaldsanalyse av tekstar frå ASK er det etter det denne forfattaren kjenner til, knapt nok gjort på norske innlærardata ${ }^{5}$. Eg har nærlese dei 38 tekstane, koda tekstdelar som utgjer eit tematisk heile i kvar tekst for deretter å samkategorisera tema som heng saman i eit større tema. Etter at eg hadde nærlese tekstane og koda dei for innhald, sat eg att med mange tematiske kategoriar. Som påpeika av Pavlenko (2007) referert over, er eit problem ved slike innhaldsanalysar at dei fort vert "smørbrødlister" av observasjonar, og kjem ikkje vidare i analysen. Det er opplagt ein fare for at denne utforskande undersøkinga av ASK-tekstane hamnar i denne kategorien av narrative studiar. I og med at hovudføremålet er å undersøkja kva ein kan få ut av korpuset ved å granska innhaldet i tekstane ut frå ei narrativ tilnærming, meiner eg at eit slikt grep kan forsvarast. Det er dessutan ein tradisjon innanfor studiet av personlege narrativar for å granska materialet basert på "grounded theory" og gjennom "bottom-up-research". Dette er ei teoretisk og metodisk tilnærming som mellom anna Burck meiner er særleg fornuftig i eksplorative studiar (2005, s. 41-42).

I dei komande avsnitta vil eg peika på tema og illustrera med enkelte tekstutdrag som eg meiner er interessante, og som eg meiner til saman speglar ei slags breidde i det som kjem fram. Eg har altså gjort eit utval, og det betyr at det vil vera innsikter som ikkje kjem fram av denne analysen. Mellom anna viser eg ikkje til eit tema som går att i mange av tekstane, nemleg på kva måtar ein i følgje innlæraranes beskrivingar lærer norsk best. Det er også slik at tekstutdraga eg har sortert under eitt tema, av andre forskarar kan tolkast som å vera uttrykk for noko anna. Innanfor artikkelformatet er det vanskeleg å yta materialet full rettferd, men lesar kan gjennom tabell 2 i vedlegg 1 finna att alle tekstane i ASK. Etter kvart tekstutdrag oppgir eg ein kode som uttrykkjer kva for nummer narrativen har i mitt materiale (Ntall), kjønn (k eller m), førstespråk (alb, eng, pol, serbkr, so, sp eller viet), test (språkp eller høgarenivå) og utdanningsbakgrunn (høgareutd, vidareg eller grunnsk). Koden N9_k_sp_språkpr_vidareg skal då lesast slik: "narrativ nummer 9, kvinne med spansk som førstespråk som 
har teke Språkprøven og har vidaregåande utdanning frå heimlandet”. Tabell 3 i vedlegg 2 gir ein oversikt over kva kodane viser til. Meir detaljert informasjon om den enkelte innlærar finst i tabell 2 i vedlegg 1.

\section{“Gammel papagøyen lærer ikke å snakke”"}

Tittelen er teken frå overskrifta til ein av dei 25 tekstane der alder eksplisitt er nemnd. I denne undersøkinga er det ikkje eit poeng i seg sjølv å jamføra talet på kor mange gonger ulike tema vert nemnde, men det må seiast at alderstemaet stikk seg mykje ut. Av dei 25 tekstane der alder er nemnd, framstiller 22 av desse vaksen alder som ei hindring i læringsprosessen. Dette kan vera eit uttrykk for at det å læra språk i vaksen alder vert opplevd som utfordrande, men det reint kvantitative forholdet kan også reflektera oppgåveformuleringa. I oppgåva vert kandidatane indirekte inviterte til å reflektera over alder og språklæring fordi dei vert bedne om å snakka om vaksen språklæring, ikkje språklæring generelt. Det er difor meir interessant å sjå nærare på korleis innlærarane reflekterer rundt effektane av alder, enn å leggja særleg vekt på talet på tekstar som tematiserer aldersfaktoren. Fleire av innlærarane viser til ei slags nedsett evne i kognitiv fungering, til dømes i form av dårlegare hukommelse. Men også dårlegare evne til omstilling og evne til å koma i kontakt med majoritetsspråklege, vert trekte inn som forklaring:

1. Jeg syns at å lcere seg språk i en voksen alder er det vanskelig, særlig til de som er over 50 års alderen. Jeg har sett mange personer som har kommet til Norge i en alder mellom 45-60 år, og de er det så vanskelig p.g.a språket. Det blir veldig vanskelig for de å lcere seg en ny språk. De har ikke så god huskommelse lenger og det blir vanskelig å komme seg inn i en annen kultur også. På grunn av språket også, blir de isolert eller de skaffe seg venner fra sammen nasjonalitet så det blir enda vanskelig at de kan lcere seg den nye språk og enda verre er at de integrerer seg ikke i den nye samfunnet. (N9_k_sp_språkpr_vidareg)

Ein annan klar tendens i tekstane som trekkjer inn alder, er at barns og vaksnes andrespråksutvikling vert framstilt som noko ulike læringsprosessar:

2. Å lcere et språk når man er voksen, er ikke veldig lett. Det er mange forskjellige ting som gjør denne jobben vanskelig. [...] De larer ikke så ført som før. Veldig ofte voksene trenger mye mer tid til å lcere et språk enn barna. Også trenger de å lese og å konsentrere seg enda mer. [...] De må forstå betydningen og hvorfor er det sånn. Jeg mener at noen ganger barna lcerer masse ting og de vet ikke hva er det eller hva det betyr. Voksen trenger å vite om regler. Reglene gir betydning til alt vi lerer.

(N14_k_sp_språkpr_vidareg) 
Barn vert framstilte som suksessfulle innlærarar som lærer meir eller mindre automatisk. Vaksne er beskrivne med ei form for nedsett evne til å læra språk, og som følgje av det treng dei ei anna tilnærming til læringsoppgåva enn barn, mellom anna eit meir eksplisitt fokus på reglar. Vaksne må gjera ein ekstra innsats for å læra språket, og vaksne bruker lengre tid på å tileigna seg språket. At vaksen andrespråkslæring er ein langsam prosess som krev tolmod, er tematisert i ei rekkje tekstar:

3. Det tar langt tid å lere et nytt språk. Det er mulig. Man må bare vœere tålmodig. (N16_k_pol_språkpr_høgareutd)

4. Man trenger mye tålmodighet. Det gjelder både dem som lcerer seg og dem som hører ikke fårståelig språk. (N15_k_pol_språkpr_høgareutd)

5. For det første må man lcere grammatikk, vokabular og mange ting som er bare en del av språket. Etterpå kommer en prosess som det er komplisert og tar masse tid [...] De tar mye tid å lcere et helt nytt språk. (N1_k_sp_høgarenivå_høgareutd)

Eit klart mindretal godtek ikkje premissen innbakt i oppgåveformuleringa, og ser ikkje alderen som eit problem, men ein føremonn:

6. Det er ikke så vanskelig å læere et fremmed språk $i$ voksen alder, fordi jeg er en av dem, og jeg prøvdde det selv, og jeg liert det uten problem. Jeg tror at det er så letere å lcere et fremmed språk i voksen alder enn å lcere en ung alder, fordi den voksen alder kan ikke ta bare og høre om det lcereren fortalte, men kan han/hun også arbeide hjemme og gjøre mye forskjellige oppgaver som er ikke inkludert i skoleprogrammet. På grunn av at den voksen alder arbeider selvstendelig, er det letere for ham/henne å læere så fort som mulig. (N7_m_so_språkpr_høgareutd)

Dei tre innlærarane som oppfattar språklæring i vaksen alder som mindre problematisk, har alle høgare utdanning. Dette er ikkje overraskande ut frå det ein veit om betydinga av utdanningsbakgrunn for læringstempo og læringsutfall (jf. t.d. Bugge, Carlsen \& Gujord, 2014). Det er derimot noko påfallande at utdanningsbakgrunn vert nemnd som ein vesentleg faktor av berre ein innlærar:

7. Det er veldig viktig når menneskene skal få å lcere annet språk, å kjenner hva slag utdanelse har den personen. Lœererne bør vite forskjellige ting om elevene sine for eksempel: utdanelse, elder, yrker, slik i løpet av kur de får vite om hva temcer trenger sine elevene å lcere mer, og kanskje mulighet å organisere grupper av personner fordi noen lerer veldig mye lett og andre trenger mer tid. (N23_k_sp_språkpr_høgareutd) 


\section{"De som vil og har sterk vilje de kan gjore mye"7}

Vilje og motivasjon er generelt gitt ei nøkkelrolle av dei vaksne språkinnlærarane som ein kompenserande faktor for høg alder:

8. For å lcere et fremmed språk i voksen alder det er ikke lett, men det man kan greie hvis en har vilje og håp for et nytt liv i det landet som er kommet. (N13_m_alb_språkpr_høgareutd)

9. I voksen alder kunne det være vanskelier å begyne å lcere [...] Jeg synes a likevel at alt er mulig, hvis man har en sterk motivasjon. (N29_k_pol_språkpr_høgareutd)

Motivasjon er ved sida av språklæringsevne ("language aptitude”) halden fram som ein av dei to viktigaste individuelle faktorane (Dörnyei, 2005). Sjølv om motivasjon altså er langt framme i medvitet til dei vaksne innlærarane, er det berre i ein tekst at språklæringsevne kan tolkast som å verta tematisert:

10. Det finnes folk også som har "sinne" for fremmed språk.

(N12_k_alb_språkpr_vidareg)

\section{“Noen ganger følgte jeg meg som barn”8}

At språklæring i den postkritiske alderen skil seg frå språklæring før, at andrespråkslæring er ein langsam prosess, og at motivasjon er ein sentral affektiv faktor er godt dokumentert i andrespråksforskinga (Gujord, 2013). Men ein tendens i materialet som i mindre grad er framme i forskingslitteraturen, er beskrivingane av det ubehaget som følgjer med det å vera vaksen i eit nytt samfunn og kultur utan å meistra språket som gjeld:

11. Den andre ting som gjør å lcere nytt språk vanskelig er at voksne er ofte sjenert at når de prøver å snakke, når de gjør mange feiler. De føler seg dumt og foretrekker å ikke snakke enn å snakke med feiler. Det er mye bedre, comfortable å snakke engelsk eller annet språk de kan.

(N4_k_pol_språkpr_høgareutd)

12. Når man er voksen da er man flau å snakke, spesiellt hvis man vet at man sier det ikke riktig. Og det går sakte å læere, ofte jobber man eller spesiellt kvinner som har familiet og har ikke tid til å lere. Derfor tror jeg, at det beste er å lcere språk når man er i barn alder eller på ungdomsalder. (N30_k_pol_språkpr_vidareg)

Desse beskrivingane kan sjåast i samanheng med utdraga der innlærarane fortel om korleis det er å vera vaksen i eit nytt land utan å kunna språket. Innlærarane skriv om tap av vaksenautoritet og sjølvstende (13 og 14), om å ikkje kunne vera seg sjølv på andrespråket (15), og om utanforskap (16): 
13. Jeg følte meg dom og hendikep kan jeg si når jeg motte gå i buttikken eller til legen og kunne ikke si noe, så motte jeg gå alltid sammen med min mann. (N26_k_al_språkpr_vidareg)

14. Det er var vanskelig til meg å høre og å forstå. Noen ganger følgte jeg meg som barn. (N18_k_pol_språkpr_høgareutd)

15. [...] jeg oppføre meg litt forskellig når jeg snakker norsk. Jeg blir mer stile og seriøs. I midlertid snakker jeg spansk blir jeg mer slappavende og ikke så seriøs. (N3_k_sp_høgarenivå_høgareutd)

16. Da jeg kom forste gang i Norge jeg vet ikke ingen ord, og jeg så på alle menneskene hva de snakke. (N24_k_al_språkpr_vidareg)

\section{“Språk er nøkkel til alle dørene" ${ }^{9}$}

Det er interessant å sjå variasjonen i grunnane til å læra norsk som innlærarane oppgir. Medan nokre framhevar dei instrumentalistiske årsakene til å læra norsk, som tilgang til jobb og av omsyn til forsørgjaransvar $(17,18)$, oppgir andre tilgang til kultur (19) og sosial kontakt (20) som motiv for norsklæringa:

17. Det blir letere å skape seg jobb hvis man kan snakke språket $i$ den landet vi bor i. (N19_m_sp_språkpr_høgareutd)

18. Jeg ønsker meg en jobb for å næemere med nordmann. Jeg har lært mye på foreldere møte og i barnehagen [...] Jeg må lcere mye. For meg og for tre barna mi. De skal vokser opp i Norske samfunnet.

(N32_k_vi_språkpr_høgareutd)

19. Jeg liker veldig god å lcere norsk. Det er en god oplevelse fordi jeg har lcert et nytt språk, men jeg har læert også mye om den norske kulturene [...] Jeg synes at det er en utrollig oplevelse å lcere norsk, for eksempel: I @sted ${ }^{10}$ er berømt Henrik Ibsen og for meg er det nydelig kan lese og høre hjemme dukke på det originale språket. (N21_k_sp_språkpr_høgareutd)

20. Jeg er veldig glad og hyggelig for nå jeg vet norsk. Forst og fremst jeg er veldig glad når jeg måtte snakke norsk med venninene mine som er noske, på helsesenter, legen telefon alt er mulig. (N24_k_al_språkpr_vidareg)

Å meistra språket er også noko meir fundamentalt, det betyr tryggleik (21), og det betyr ikkje minst sjølvstende (22 og 23):

21. [...] hvis du kan språke da føler du deg trugt. (N26_k_al_språkpr_vidareg)

22. Tilslutt synes jeg å lcere et nytt språk er vanskelig og for voksne mennesker, men det er viktig å læere språk. Fordi språk gir folk god føllelse og man trenger ikke at noen skal være tolk for deg. (N28_k_so_språkpr_vidareg) 
23. Det er en stor glede hvis du kan lese og forstår det som står i avisen og når du se på tven eller når du gå på kino trenger du ikke spør ingenting til den som sitter ved siden av deg. (N19_m_sp_språkpr_høgareutd)

\section{"Det var bare kamp om å overleve, finne et anet sted for familien min" 11}

I materialet står innlærarane fram som tilsynelatande motiverte for læringsoppgåva. Men me veit at ikkje alle kjem ut av norskopplæring med eit nivå som gjer at dei har ein realistisk sjanse på arbeidsmarknaden. Alder er nemnd som ein faktor som gjer prosessen vanskeleg, men i tekstmaterialet kjem også ei anna mogleg forklaring til syne:

24. Det er mange år siden jeg kom til Norge. Man hadde ikke tid å tenke på noen ting. Det var bare kamp om å overleve, finne et anet sted for familien min. Og vi var heldige. Vi fant et nytt hjem her i Norge. Det var ikke lett, men ting kom på plass etter hvert. (N2_k_serbkr_høgarenivå_høgareutd)

25. Mange som kommer fra andre land må læere seg veldig furt, for å fårsto alt som skjer rundt omkring. Det er litt stresende fordi man trenger mye tid for å venne seg til det nye språket. Ganske ofte må man jobbe samtidig. Voksne har mange oppgaver. For eksempel med barn, med hjemarbaid og med jobb o.s.v. [...] De voksne menneskene er veldig travel i dag. Det er en årsak som kan forstyrre for å lcere det nye språket. (N15_k_pol_språkpr_høgareutd)

26. A lere et fremmed språk i voksen alder er ikke lett. Fordi når man blir voksen har man mye å gjør eller mye å tenke på. Hos en voksen er tanken helt full av masse ting. (N28_k_so_språkpr_vidareg)

Av dette kan ein tolka at totalsituasjonen eller totalbelastninga av å vera nyleg komen til landet, gjer det vanskeleg å få tid og krefter til å læra norsk.

\section{“Hvorfor har stor forskjell mellom bøka, skolen og arbeidslivet?" 12}

Eit tema som også går att, gjeld språklege utfordringar i norsk, og hovudsakleg peikar informantane på at grammatikk og uttale er vanskeleg. Dei fleste som tematiserer dette, gjer det i eit kontrastivt perspektiv, og uttrykkjer at avstanden mellom førstespråket og norsk spelar inn på tileigninga. Ein innlærar beskriv dessutan at det å læra norsk, inneber også å tenkja på ein annan måte:

27. Jeg synes det er rart å føle meg forskjellig når jeg skifter språk. I tillegg er logiskken annenledes. For eksempel, hvis vi tar opp preposisjoner, blir de spanske reglene veldig forskjellige fra de norske. Man må legge et bildet $i$ hodet for å velge preposisjoner på norsk, mens på spansk er det reglene som bestemmer brukelsen av preposisjoner. (N3_k_sp_høgarenivå_høgareutd) 
Denne beskrivinga er interessant, særleg i lys av teoriutviklinga innan transferforskinga dei siste tiåra som har hatt eit større fokus på korleis konseptuelle skilnadar mellom førstespråket og målspråket, og ikkje berre lingvistiske, påverkar tileigninga. Ein annan meir påfallande og mykje mindre utforska problematikk, er at innlærarane finn talemålsvariasjonen, og avstanden mellom språket innanfor og utanfor klasserommet, som eit spesielt krevjande trekk ved norskinnlæringa:

28. Det med forskjellige dialekter gjøre det enda vanskeligere. (N10_k_sp_språkpr_høgareutd)

29. Det som gjør at norsk blir vanskelig for oss er dialektene som folk snakker med. Vi lcerer og hører på kasseter på skole, men når vi er ute er de veldig vanskelig å farsto hva folk sier. (N25_m_serbkr_språkpr_høgareutd)

30. Men jeg synes Nordmann snakker så forskjellig, både dialek på TV og radio. Noen ganger, mistet jeg tålmodighet. Hvorfor har stor forskjell mellom bøka, skolen og arbeidslivet? Jeg drømmer om en jobb, der kan jeg læere mye, mye mer norsk. Jeg har vanskelig å forstå norsk. Mennesker snakker så fort, eller??? (N32_k_vi_språkpr_høgareutd)

Det er verdt å merkja seg at dette dukkar opp i tekstar som i utgangspunktet ikkje handlar om språklæring, men om arbeidsliv (31), bumiljø (32), å treffe folk (33) og flytting (34):

31. Jeg skal prøve å skrive om mitt yrket. At blir en sjåføren på tunge kjøretøy han må gå på en skol [...] For meg selv var det veldig vanskelig å følge undervisning. Det var årsak at de to lerere snakket forfort og de snakket lokal dialekt [...] Jeg har hatt i begynelse veldig vanskelig. Mye kjøring, fremmed språk som er enda mer fremmed i praksis enn på skolen og i bøker. (N35_m_serbkr_språkpr_høgareutd)

32. Vi har to næer naboer Et bonde som heter @navn. Han er så venlig! Men han snakker med en veldig vanskig dialekt. Noen ganger er det vanlskelig å forstår han, men vi grei det mest tiden. (N37_m_al_språkpr_høgareutd)

33. [...] og der bodde jeg sammen med familien til min venninne og de snakket Bergensk dialekten så jeg kjønte ingenting først omgangen og jeg gjentok hele tiden "kan du gjente", men etter hvert ble jeg bedre å forstår. (N39_m_al_språkpr_høgareutd)

34. Jeg med min familie skal flytter til @sted.Vi har fått ny kommune fra Udi. For oss er vanskelig for å skifte byen nå [...] Vi må begynne fra nytt, slik at vi har kommt for første gang i Norge. For barna er også vanskelig, de skal bytter skolen, venner og læererne [...] Vi har hørt at $i @ s t e d$, de snakker lit 
førsjell enn her i@sted.De har andre dialekt.Vi har lcert her bokmå, kanskje i@sted må vi lcerer videre,ny dialekt.

(N36_m_eng_språkpr_vidareg)

I utdrag (34) over er bokmål nemnd. Den særskilte norske situasjonen med to offisielle skriftspråk er tydeleg omtala i eit tilfelle av ein innlærar som problematiserer det å få bokmål som opplæringsspråk i ein kommune med nynorsk som administrasjonsspråk:

35. Jeg går på skolen i mange år men jeg kan ikke snakke bra norsk. Nordmann snakker så fort og de bruker to forskjellig språk og dialek er veldig vanskelig. På skolen læerer jeg bokmål men jeg bor i kommunen som snakker nynorsk. Jeg får stor problem når jeg snakker norsk. (N6_k_vi_språkpr_grunnsk)

\section{Diskusjon og oppsummering}

Det overordna siktemålet i denne artikkelen har vore å undersøkja ASK som potensielt kjeldemateriale for studiet av vaksen andrespråkslæring med utgangspunkt i innlærarane sine eigne refleksjonar og tankar om språklæring. Basert på faglitteraturen på området, særleg Pavlenko $(2007,2008)$ og De Fina (2009), har eg argumentert for at eit utval på 38 tekstar kan reknast som personlege narrativar, sjølv om tekstane er produserte under ein testsituasjon. Tekstane er responsar på ulike oppgåveformuleringar, og det varierer i kva grad tekstane direkte står fram som å byggja på sjølvopplevd erfaring. Likevel har tekstane til felles at dei uttrykkjer ein vaksen innlærars refleksjonar rundt språk og språklæring.

ASK-korpuset har så langt i all hovudsak vore nytta som datakjelde til innsikt i grammatisk og leksikalsk andrespråksutvikling. I denne undersøkinga har intensjonen vore å granska kva ein kan få ut av ASK-korpuset om språklæring ved å studera synspunkt og beskrivingar sette fram av dei vaksne innlærarane sjølve. Undersøkinga har difor vore utforskande, og analysen har i liten grad gått i djupet. Først og fremst har analysen hatt som funksjon å visa breidda i innhaldet i tekstane, innhald som komande studiar kan gå grundigare og meir målretta analytisk til verks i.

Som eg har gjort greie for tidlegare, kan ein ha ulike analytiske inngangar til eit narrativmateriale. Ein kan ønskja å finna ut korleis innlærarane sjølve tenkjer rundt eigen læringsprosess (subject reality) og/eller ein kan ønskja å finna ut korleis noko er eller var i omgjevnaden rundt innlæringa (life reality). I nyare tid har forskarane i større grad vore interesserte i å utforska text reality, det vil seia korleis innlærarane posisjonerer seg i tekstane i forhold til diskursen. I prinsippet kan ASK nyttast til å utforska alle desse tre aspekta. Den analytiske inngangen til narrativane i denne undersøkinga har mest til felles med studiar av 
subject reality, sjølv om tekstutdraga av korleis innlærarane opplever totalsituasjonen også kan seiast å gi informasjon om life reality.

Eit sentralt spørsmål i denne artikkelen er naturlegvis korleis dei personlege narativane kan vera nyttige som kjelde til innsikt i læringsprosessen til vaksne innlærarar. Eg meiner at fleire av tekstutdraga viser at delar av tekstmaterialet i ASK har dei kvalitetane som Pavlenko (2007, s. 165) trekkjer fram, nemleg å gi eit “insider’s view” på læringsprosessen. Dette gjeld særleg dei tekstutdraga der innlærarane skriv om det å mangla språket som vaksen, det å vera flau, kjenna seg som handikappa og usjølvstendig, men også tekstutdraga som beskriv korleis det på grunn av livssituasjonen er vanskeleg å få tid og overskot til språklæringa. Som mellom anna Pavlenko og De Fina understrekar, er det viktig å ta konteksten for narrativen inn i analysen, og det er fleire stader i dette materialet der ein må vera merksame på at innlærarane ikkje beskriv faktiske realitetar, men posisjonerer seg i forhold situasjonen. Til dømes kan ein tenkja seg at innlærarane som skriv om viktigheita av motivasjon og vilje, ønskjer å stå fram som flittige språkinnlærarar. Det same gjeld utdraga der innlærarane skriv om kor viktig det er å læra norsk, til dømes for å kunna koma seg i jobb. Det at ein skal ta konteksten inn i analysen, betyr likevel ikkje at erfaringane innlærarane fortel om ikkje kan vera reelle for dei og relevante for oss. Refleksjonane og beskrivingane om det å ikkje ha språket, står også fram som autentiske og baserte på erfaring, og ikkje som strategisk skriving i ein testsituasjon. Ein del av desse beskrivingane har gjenklang i faglitteraturen om vaksenlæring (til dømes Wahlgren, 2010), der trygge læringssituasjonar og det å kunna vera sjølvstendige, er viktige læringsfaktorar. Men denne typen innsikt frå det vaksenpedagogiske feltet er knapt innreflektert i innføringsbøker i andrespråkstileigning. Eg vil difor meina at dette tekstmaterialet frå ASK, som trass alt er lett tilgjengeleg for mange, er viktig å ta i bruk også på denne måten, og kanskje særleg bli nytta som kjelde til innsikt i undervisninga av studentar innan faget (framtidige lærarar, etter- og vidareutdanning). Å lesa innlærarane sine eigne beskrivingar av det å vera ein vaksen språkinnlærarar i ein ny kulturkontekst, kan vera ein måte å løfta fram sentrale aspekt som ikkje er så godt synlege på pensumlistene. Det å lesa innlæraranes eigne tankar og erfaringar rundt dette, kan også vera ein god måte å formidla betydinga av affektive tilhøve rundt innlæringa fordi ein får nærleik til stoffet gjennom å lesa det innlærarane sjølve fortel. Slik eg ser det, har altså dei personleg narrativane i ASK ein klar nytteverdi i undervisninga i norsk som andrespråk og andrespråkspedagogikk. Dette er også i tråd med Murray (2009) som hevdar at denne typen data, personlege narrativar, er særskilt viktig i lærarutdanninga.

Som nemnt tidlegare, peikar Murray (2009) i lag med fleire også på ein annan viktig nytte som denne typen materiale kan han, nemleg å la marginaliserte grupper koma til orde. Denne typen materiale er soleis av særskilt interesse for utdanningsmyndigheiter og politikarar. Slik eg ser det, kan dette også gjelda tekstmaterialet i ASK. Det siste året har opplæringspolitikk i form av rettar og 
plikter for innvandrarar vore mykje debattert. Styresmaktene har innført nye og skjerpa krav til vaksne innvandrarar, og mange fagfolk har problematisert dei nye krava av omsyn til enkelte innvandrargruppers særskilte behov. Ein del av tekstane i ASK er av ein slik karakter at dei gir ein nærleik til innlærarane og deltakarane i opplæringa. Det strevet mange av dei beskriv, kombinert med det sterke agens me ser i materialet i form av stor tru på at nok motivasjon og vilje vil gi resultat til trass for hindringar, er relevant å trekkja inn som kjelde til innsikt også i slike diskusjonar. Personlege narrativar kan potensielt gi utdanningsmyndigheitene eit innblikk i korleis det er å vera vaksne språkinnlærarar i eit nytt samfunn og ein ny kultur, kor viktig dette faktisk er for innvandrarane, og kor mykje som står på spel.

Eg vil også meine at forskarar kan ha nytte av dette materialet i meir vitskapleg forstand. Pavlenko (2007, s. 165) hevdar også at studiet av personlege narrativar kan tilføra feltet ny innsikt fordi betydinga av nye samanhengar som forskarane ikkje har vore medvetne om, kan koma til syne gjennom innlærarane sine personlege beskrivingar. Døme på det i dette materialet er innlærarane si påpeiking av den store avstanden mellom det språket dei møter i undervisninga og det språket dei møter elles i samfunnet, utfordringane den særskilte norske språksituasjonen med omfattande variasjon i skrift og tale stiller innlærarane overfor, samt beskrivingane av totalsituasjonen eller livssituasjonen. Ifølgje Husby (2015, s. 330-331) tilpassar dei fleste lærarane talemålet sitt til eit bokmålsnært talemål, men ispedd intonasjonsmønsteret frå talemålet dei elles nyttar. Denne strategien i klasserommet har i liten grad vore eit diskusjonstema, sjølv om det er i ferd med å få eit aukande fokus. Det er også ein innlærar som problematiserer opplæringsspråket, og som uttrykkjer misnøye med å få opplæring i bokmål når ho bur i ein kommune med nynorsk som administrasjonsspråk. Desse observasjonane viser at desse tekstane i ASK kan innehalda innsikter som bør granskast nærare.

For ein forskar kan det også vera interessant å granska kva innlærarane ikkje nemner i tekstane om språklæring. Det er som eg har nemnd tidlegare, berre ein innlærar som peikar på utdanningsbakgrunn som ein sentral faktor. Det kan også vera interessant å sjå nærare på korleis innlærarane oppfattar språklæring. I tekstutdraga eg har vist, kjem det til dømes fram eit bilete av skilnaden mellom vaksnes og barns andrespråkslæring. Det vert hovudsakleg teikna eit bilete av barns andrespråkslæring som ukomplisert og rask, i motsetnad til det strevet som dei vaksne må gjennom. Sjølv om faglitteraturen peiker på at barn og vaksne på nokre punkt tileignar seg andrespråket ulikt, har ikkje ei slik beskriving av skilnaden støtte i forskinga.

Oppsummert vil eg meina at denne utforskande undersøkinga har vist at meir "utypiske” studiar basert på tekstar frå ASK har noko føre seg. Studiar som ser vekk frå formmessige og leksikalske val, og i staden utforskar innhaldet i ASKtekstar som kan kategoriserast som personlege narrativar, kan få fram ein annan type innsikt om læringsprosessen. Innlæraranes refleksjonar omkring og erfaring 
med språklæring i vaksen alder kan på ulike måtar nyttast i undervisning i norsk som andrespråk og andrespråkspedagogikk, og vera ei viktig kjelde til innsikt for utdanningsmyndigheiter og politikarar. Tekstane kan også bidra i meir vitskapleg forstand ved å avdekkja og synleggjera aspekt som har fått mindre merksemd av forskarane, og som forskarane kan granska vidare i anna empirisk materiale. Framtidige studiar bør kunne utforska ulike aspekt ved innlæraranes refleksjonar, også basert på tekstar frå ASK, og gjerne med eit text realityperspektiv. Språkkrav og integrering vert sett på som tett samanbundne i diskursen om innvandring i dag. Ein studie av eit utval av ASK-tekstar der ein ser på korleis testtakarane posisjonerer seg som språkinnlærarar i det norske samfunnet med høgare krav til norskkunnskapar, ville difor vore eit interessant og originalt tilskot til fagfeltet.

\section{Referansar}

Atkinson, R. (1998). The life story interview. I J. F. Gubrium \& J. A. Holstein (red.), Handbook of interview research. Context \& method (s. 121-140). Los Angeles: Sage Publications.

Barkhuizen, G. (2015). Narrative inquiry. I B. Paltridge \& A. Phakiti (red.), Research Methods in Applied Linguistics (s. 69-185). London/New York: Bloomsbury Publishing.

Barkhuizen, G. (2008). A narrative approach to exploring context in language teaching. ELT Journal, 62(3), 231-239.

Barkhuizen, G., Benson, P. \& Chik, A. (2014). Narrative inquiry in language teaching and learning research. London/New York: Routledge.

Berggreen, H., Sørland, K. \& Alver, V. (2012). God nok i norsk? Språk og skriveutvikling hos elever med norsk som andrespråk. Oslo: Cappelen.

Berman, R. (2001). Narrative development in multilingual contexts: A cross-linguistic perspective. I L. Verhoeven \& S. Strömqvist (red.), Narrative development in a multilingual context (s. 419-428). Amsterdam: John Benjamins.

Berman, R. \& Slobin, D. (1994). Relating events in narrative. A crosslinguistic developmental study. Mahwah, NJ: Lawrence Erlbaum.

Block, D. (2003). The social turn in second language acquisition. Edinburgh: Edinburgh University Press.

Breivega, K. \& Johansen, S. P. (2016). Frå sjanger til teksttype i skriveopplæringa? Norsklcereren 2, 50-62.

Bruner, J. (1987). Life as a narrative. Social research, 54(1), 11-32.

Bruner, J. (1990). Acts of meaning. Cambridge, MA: Harvard University Press.

Bugge, E., Carlsen, C. H. \& Gujord, A. K. H. (2014). Variasjon i lceringsutfall blant kandidatar som går opp til Norskprøve 2 og Norskprøve 3: Utkast til analysemodell. Innlegg halde på Den sjette nasjonale forskerkonferansen om norsk som andrespråk, Universitetet i Stavanger.

Burck, C. (2005). Multilingual living. Explorations of language and subjectivity. New York: Palgrave Macmillan.

Canagarajah, A. S. (1996). From critical research practice to critical research reporting. TESOL, 30(2), 321-331. 
Chik, A. (2008). How experience shapes individual differences among second language learners: a biographical study of Hong Kong learners in five age groups. PhDavhandling, The University of Hong Kong.

Connelly, F. M. \& Clandinin, D. J. (1990). Stories of Experience and narrative inquiry. Educational researcher, 19(5), 2-14.

De Fina, A. (2009). Narratives in interviews - the case of accounts. Narrative Inquiry, 19(2), 233-58.

Dörnyei, Z. (2005). The psychology of the language learner: individual differences in second language acquisition. Mahwah, NJ: Lawrence Erlbaum Associates.

Gujord, A. K. H. (2013). Individuelle skilnadar i andrespråkslæringa: Om status og trendar i forskinga. NOA, 29(2), 5-36.

Husby, O. (2015). Andrespråk og uttale. I K. M. Eide (red.), Norsk andrespråkssyntaks (s. 325-400). Oslo: Novus.

Murray, G. (2009). Narrative Inquiry. I J. Heigham \& R. A. Croker (red.), Qualitative research in applied linguistics. A practical introduction (s. 45-65). Basingstoke: Palgrave Macmillan.

Nistov, I. (2001). Referential choice in L2 narratives. A study of Turkish adolescent immigrants learning Norwegian. Acta Humaniora nr. 99, Universitetet i Oslo.

Norton, B. \& Early, M. (2011). Researcher identity, narrative inquiry, and language teaching research. TESOL QUARERLY, 45(3), 425-439.

Norton, B. \& McKinney, C. (2011). An identity approach to second language acquisition. I D. Atkinson (red.), Alternative approaches to second language acquisition (s. 73-94). New York: Routledge.

Nunan, D. \& Choi, J. (2010). Language and Culture. Reflective narratives and the emergence of identity. London: Routledge.

Pavlenko, A. (2004). 'The making of an American'. Negotiation of identities at the turn of the twentieth century. I A. Pavlenko \& A. Blackledge (red.). Negotiation of identities in multilingual contexts (s. 34-67). Clevedon: Multilingual Matters.

Pavlenko, A. (2007). Autobiographic narratives as data in applied linguistics. Applied linguistics, 28(2), 163-188.

Pavlenko, A. (2008). Narrative analysis in the study of bi- and multilingualism. I M. Moyer \& Li Wei (red.), The Blackwell Guide to Research Methods in Bilingualism (s. 311-325). Oxford: Blackwell.

Riessman, C. K. (2001). Analysis of personal narratives. I A. E. Fortune, W. J. Reid \& R. L. Miller (red.), Qualitative research in social work (s. 168-191). New York: Columbia university press.

Schumann, F. (1980). Diary of a language learner: A further analysis. I R. Scarcella \& S. Krashen (red.), Research in second language acquisition. Selected papers of the Los Angeles Second language acquisition forum (s. 51-57). Rowley, MA: Newbury House.

Selj, E. (2010). Utfordringer ved narrativ tekstskriving når norsk er andrespråk. Nordand, 2, 35-59.

Svendsen, B. A. (2004). Så lenge vi forstår hverandre. Språkvalg, flerspråklige ferdigheter og språklig sosialisering hos norsk-filippinske barn i Oslo. Acta Humaniora nr. 216, Universitetet i Oslo.

Taniguchi, S. (2010). Transforming identities in and through narrative. I D. Nunan \& J. Choi (red.), Language and Culture. Reflective narratives and the emergence of identity, (s. 208-214). London/New York: Routledge.

Tenfjord, K., Hagen, J. E. \& Johansen, H. (2009). Norsk andrespråkskorpus (ASK) - design og metodiske forutsetninger, NOA, 2, 52-80. 
Vasquez, C. (2007). Moral stance in the workplace narrative of novices. Discourse studies, 9(5), 653-675.

Vasquez, C. (2011). Narrative knowledging in TESOL. TESOL, 45(3), 535-545.

Wahlgren, B. (2010). Voksnes læreprocesser. Kompetenceudvikling i uddannelse og arbejde. København: Akademisk forlag.

Young, R. F. (2013). Qualitative reserach. I P. Robinson (red.), The Routledge encyclopedia of second language acquisition (s. 536-539). New York: Routledge. 


\section{Vedlegg 1}

Tabell 2 Fordeling av tekstane på individ på utvalde personvariablar og korresponderande idnummerering i ASK

\begin{tabular}{|c|c|c|c|c|c|c|c|c|}
\hline $\begin{array}{l}\text { Narr. } \\
\text { nr. }\end{array}$ & Kjønn & Alder & Førstespråk & Utdanning & Prøve & Tema & Heimland & $\begin{array}{l}\text { Id-n. } \\
\text { ASK }\end{array}$ \\
\hline N1 & $\mathrm{K}$ & 28 & spansk & høgsk/univ. & Høgare nivå & Dikt om språk & Chile & h0666 \\
\hline $\mathrm{N} 2$ & $\mathrm{~K}$ & 38 & serbokroatisk & høgsk/univ. & Høgare nivå & Dikt om språk & $\begin{array}{l}\text { Bosnia- } \\
\text { Hercegovina }\end{array}$ & h0671 \\
\hline N3 & $\mathrm{K}$ & 27 & spansk & høgsk/univ. & Høgare nivå & Dikt om språk & Mexico & h0672 \\
\hline N4 & $\mathrm{K}$ & 28 & polsk & høgsk/univ. & Språkprøven & Framandspråklæring & Polen & s0734 \\
\hline N5 & $\mathrm{K}$ & 25 & polsk & høgsk/univ. & Språkprøven & Framandspråklæring & Polen & s0732 \\
\hline N6 & $\mathrm{K}$ & 40 & vietnamesisk & grunnskule & Språkprøven & Framandspråklæring & Vietnam & s0731 \\
\hline N7 & $\mathrm{M}$ & 34 & somali & høgsk/univ. & Språkprøven & Framandspråklæring & Somalia & s0730 \\
\hline N8 & $\mathrm{K}$ & 43 & spansk & vidareg. & Språkprøven & Framandspråklæring & Chile & s0041 \\
\hline N9 & $\mathrm{K}$ & 41 & spansk & vidareg. & Språkprøven & Framandspråklæring & Chile & s0042 \\
\hline N10 & $\mathrm{K}$ & 36 & spansk & høgsk/univ. & Språkprøven & Framandspråklæring & $\begin{array}{l}\text { Dominikanske } \\
\text { Republikk }\end{array}$ & s0043 \\
\hline N11 & $\mathrm{M}$ & 34 & albansk & høgsk/univ. & Språkprøven & Framandspråklæring & Albania & s0045 \\
\hline N12 & $\mathrm{K}$ & 36 & albansk & vidareg. & Språkprøven & Framandspråklæring & $\begin{array}{l}\text { Serbia- } \\
\text { Montenegro }\end{array}$ & s0048 \\
\hline N13 & $\mathrm{M}$ & 38 & albansk & høgsk/univ. & Språkprøven & Framandspråklæring & $\begin{array}{l}\text { Serbia- } \\
\text { Montenegro }\end{array}$ & s0049 \\
\hline N14 & $\mathrm{K}$ & 23 & spansk & vidareg. & Språkprøven & Framandspråklæring & Spania & s0160 \\
\hline N15 & $\mathrm{K}$ & 36 & polsk & høgsk/univ. & Språkprøven & Framandspråklæring & Polen & s0161 \\
\hline N16 & $\mathrm{K}$ & 29 & polsk & høgsk/univ. & Språkprøven & Framandspråklæring & Polen & s0162 \\
\hline N17 & $\mathrm{K}$ & 30 & polsk & høgsk/univ. & Språkprøven & Framandspråklæring & Polen & s0164 \\
\hline N18 & $\mathrm{K}$ & 39 & polsk & høgsk/univ. & Språkprøven & Framandspråklæring & Polen & s0165 \\
\hline N19 & $\mathrm{M}$ & 30 & spansk & høgsk/univ. & Språkprøven & Framandspråklæring & $\begin{array}{l}\text { Dominikanske } \\
\text { Republikk }\end{array}$ & s0167 \\
\hline N20 & $\mathrm{M}$ & 36 & spansk & høgsk/univ. & Språkprøven & Framandspråklæring & Mexico & s0170 \\
\hline N21 & $\mathrm{K}$ & 29 & spansk & høgsk/univ. & Språkprøven & Framandspråklæring & Colombia & s0172 \\
\hline N22 & $\mathrm{K}$ & 40 & spansk & høgsk/univ. & Språkprøven & Framandspråklæring & Colombia & s0174 \\
\hline N23 & $\mathrm{K}$ & 33 & spansk & høgsk/univ. & Språkprøven & Framandspråklæring & Colombia & s0175 \\
\hline N24 & $\mathrm{K}$ & 31 & albansk & vidareg. & Språkprøven & Framandspråklæring & Makedonia & s0279 \\
\hline N25 & $\mathrm{M}$ & 25 & albansk & høgsk/univ. & Språkprøven & Framandspråklæring & Makedonia & s0281 \\
\hline N26 & $\mathrm{K}$ & 42 & albansk & vidareg. & Språkprøven & Framandspråklæring & $\begin{array}{l}\text { Serbia- } \\
\text { Montenegro }\end{array}$ & $\mathrm{s} 0283$ \\
\hline N27 & $\mathrm{M}$ & 34 & albansk & vidareg. & Språkprøven & Framandspråklæring & $\begin{array}{l}\text { Serbia- } \\
\text { Montenegro }\end{array}$ & s0285 \\
\hline N28 & $\mathrm{K}$ & 27 & somali & vidareg. & Språkprøven & Framandspråklæring & Somalia & s0716 \\
\hline N29 & $\mathrm{K}$ & 26 & polsk & høgsk/univ. & Språkprøven & Framandspråklæring & Polen & s0717 \\
\hline N30 & $\mathrm{K}$ & 26 & polsk & vidareg. & Språkprøven & Framandspråklæring & Polen & s0718 \\
\hline N31 & $\mathrm{K}$ & 51 & polsk & høgsk/univ. & Språkprøven & Framandspråklæring & Polen & s0719 \\
\hline N32 & $\mathrm{K}$ & 35 & vietnamesisk & høgsk/univ. & Språkprøven & Framandspråklæring & Vietnam & s0720 \\
\hline N33 & $\mathrm{K}$ & 28 & polsk & høgsk/univ. & Språkprøven & Framandspråklæring & Polen & s0722 \\
\hline N34 & $\mathrm{K}$ & 32 & polsk & høgsk/univ. & Språkprøven & Framandspråklæring & Polen & s0726 \\
\hline N35 & $\mathrm{M}$ & 41 & serbokroatisk & høgsk/univ. & Språkprøven & Et yrke & Jugoslavia & s0032 \\
\hline N36 & $\mathrm{M}$ & 43 & engelsk & vidareg. & Språkprøven & Bomiljø & Storbritannia & s0194 \\
\hline N37 & $\mathrm{M}$ & 34 & albansk & høgsk/univ. & Språkprøven & Flytting & Jugoslavia & s0264 \\
\hline N38 & $\mathrm{K}$ & 27 & somali & vidareg. & Språkprøven & $\AA$ møte folk & Somalia & $\mathrm{s} 0112$ \\
\hline
\end{tabular}




\section{Vedlegg 2}

Tabell 3 Oversyn over betydinga til kodane bak tekstutdraga

\begin{tabular}{|l|l|}
\hline Kode & Betyding \\
\hline Ntall & viser til kva for nummer narrativen har i materialet for undersøkinga \\
\hline $\mathrm{k}$ & informanten er kvinne \\
\hline $\mathrm{m}$ & informanten er mann \\
\hline al & førstespråket til informanten er albansk \\
\hline eng & førstespråket til informanten er engelsk \\
\hline pol & førstespråket til informanten er polsk \\
\hline serbkr & førstespråket til informanten er serbokroatisk \\
\hline so & førstespråket til informanten er somali \\
\hline sp & førstespråket til informanten er spansk \\
\hline viet & førstespråket til informanten er vietnamesisk \\
\hline språkp & informanten har bestått Språkprøven i norsk for vaksne innvandrarar \\
\hline høgarenivå & informanten har bestått Test i norsk - høgare nivå \\
\hline høgareutd & informanten har høgare utdanning frå heimlandet \\
\hline vidareg & informanten har vidaregåande utdanning frå heimlandet \\
\hline grunnsk & informanten har grunnskuleutdanning frå heimlandet \\
\hline
\end{tabular}

\footnotetext{
${ }^{1}$ Hausten 2005 vart Språkprøven erstatta av Norskprøve 2 og Norskprøve 3. I 2014 kom ein ny omlegging til Norskprøven (http://www.vox.no/norskprove/).

2 til dømes N24_k_al_språkpr_vidareg

3 til dømes N23_k_sp_språkpr_høgareutd

${ }^{4}$ N13_m_alb_språkpr_høgareutd

${ }^{5}$ Det har vore skrive ei semesteroppgåve basert på liknande tekstutval frå ASK, og i lys av liknande teoriutval, ved Universitetet i Bergen, men denne oppgåva er utilgjengeleg, og eg har difor ikkje kunna bruke ho i arbeidet med artikkelen.

${ }^{6}$ N21_k_sp_språkpr_høgareutd

${ }^{7}$ N14_k_alb_språkpr_vidareg

${ }^{8}$ N18_k_pol_språkpr_høgareutd

${ }^{9}$ N26_k_al_språkpr_vidareg

${ }^{10}$ Står i staden for eit stadnamn av omsyn til anonymiteten til kandidaten.

${ }^{11}$ N2_k_serbkr_høgarenivå_høgareutd

12 N32_k_vi_språkpr_høgareutd
} 